This is the accepted manuscript version submitted to the Journal of Consumer Policy. The final publication is available at link.springer.com

\title{
Andrea Fejős \\ The Impact of EU Norms and Policies on Consumer Protection Enforcement in Serbia
}

Journal of Consumer Policy, Vol. 36, Issue 3, pp. 247-268

\begin{abstract}
Pursuant to its 2008 Stabilization and Association Agreement governing the process of EU integration Serbia is obliged to align its consumer protection standards (including those related to enforcement) with those of the EU. This article considers the overall approach to enforcement of consumer law in Serbia, focussing in particular on the extent to which EU enforcement principles have been successfully exported to Serbia and whether the goals of EU consumer policy have been achieved. It argues that the incorporation of EU norms has brought fundamental changes to Serbian enforcement mechanisms at a formal level, such as in relation to mediation processes as well as the introduction of injunctions for the protection of collective consumer interests. In practice, however, the impact of this incorporation is quite limited. A number of factors that restrict the practical effectiveness of the mediation processes and injunctions required by EU law are explored in the article, including weak sanctions; excessive reliance on poorly resourced consumer organizations; absence of a business culture of compliance or a sophisticated and determined consumer protection enforcement culture sufficiently grounded in expertise; as well as an overarching political, legislative and institutional instability. These factors also undermine the general aim of EU policy to achieve effective consumer protection enforcement in the Serbian context.
\end{abstract}

Key words: consumer law, implementation of consumer acquis, enforcement mechanisms, enforcement deficiencies, Serbia

\section{Introduction}

On the $29^{\text {th }}$ of April 2008 Serbia signed, and on the $10^{\text {th }}$ of October $2008^{1}$ the Serbian Parliament ratified, the Stabilization and Association Agreement (SAA), thereby formally commencing the process of European integration. The SAA provides a conditional guarantee

\footnotetext{
${ }^{1}$ Act on the Ratification of the Stabilization and Association Agreement between the European Communities and their Member States on one part, and the Republic of Serbia, on the other part, Official Gazette of the Republic of Serbia (OG RS) No. 83/08.
} 


\section{A.Fejös, The Impact of EU Norms and Policies on Consumer Protection Enforcement in} Serbia available at link.springer.com

of membership of the European Union (EU), subject to fulfilment of a number of political and economic criteria, including harmonization of the economic law of Serbia with that of the EU (Vasiljević 2009). Specifically, Art. 78 SAA obliges Serbia to align its consumer protection standards with those of the EU, such that it has an effective consumer protection system that will be achieved by a solid administrative infrastructure for market surveillance and by effective law enforcement ${ }^{2}$ (Papovic\&Fejös 2008). When the SAA was signed, the legal framework of consumer protection in Serbia was neither fully developed nor harmonized with EU legislation (Czuczai 2006). Relative to the EU consumer aquis, the then-existing Consumer Protection Act of $2005^{3}$ was often vague and incomplete, both in terms of substantive coverage and procedural provisions for enforcement.

After singing the SAA the process of adopting the consumer acquis commenced, and the process had two phases. The first mainly related to the creation of a legal framework for the development of consumer law. This involved numerous and wide-ranging legislative changes. In September 2010, a completely new Consumer Protection Act of 2010 (CPA) ${ }^{4}$ was adopted. The CPA has been modelled on France and Italy (Karanikić-Mirić 2009), and represents a comprehensive consumer code, save for consumer credit which is regulated by the Financial Services Users Protection Act of 2011 (FSUPA). ${ }^{5}$ Besides these two key consumer protection laws, other related acts have also been adopted or amended. Since there is neither space nor a need to list all of these, what is important to point out is that a substantial part of consumer acquis has been implemented, and it can therefore be said that (at least on paper) the legal protection of consumers to a relatively high level is guaranteed.

However, after the adoption of the CPA it was clear that substantive law rules are only "letters on the paper" if they are not properly enforced. Therefore, in the second phase of development, the enforcement of consumer protection rules has become the main focus. ${ }^{6}$

\footnotetext{
${ }^{2}$ See: http://ec.europa.eu/enlargement/pdf/serbia/key_document/saa_en.pdf (last access: 10. Feb. 2012)

${ }^{3}$ Zakon o zaštiti potrošača, OG RS No. 79/2005. This act replaced the first "modern" consumer protection act of Serbia, the Consumer Protection Act of 2002 (OG FRY No. 37/2002).

${ }^{4}$ Zakon o zaštiti potrošača, OG RS No. 73/10

${ }^{5}$ Zakon o zaštiti korisnika finansijskih usluga, OG RS No. 36/11.

${ }^{6}$ See the recently adopted Civil Procedure and Energy Acts, which - although of a more general scope of application - contain enforcement rules as well as the second project for strengthening consumer protection in Serbia (2011-2014) which is focussed on enforcement.
} 
A.Fejös, The Impact of EU Norms and Policies on Consumer Protection Enforcement in Serbia available at link.springer.com

This article focuses on this latter issue of enforcement. It considers the enforcement regime that has emerged in Serbia and the impact of EU consumer protection enforcement norms, i.e. to what extent have these norms been successfully exported to influence the Serbian enforcement regime? The essential argument is the following. EU norms and have brought some fundamental changes to Serbian enforcement mechanisms at a formal level. The most important of these are (i) mediation processes at the individual/alternative dispute resolution (ADR) level and perhaps more significantly (ii) the use of injunctions as a means of preventive and collective control. However, in practice, the impact of these EU based norms and, indeed, the impact of broader EU policies on the general Serbian enforcement regime remains very limited. This is due to a combination of factors. Probably the most significant overarching factor is that the mechanisms are not designed specifically for the local consumer needs irrespective of whether the issue is ineffective sanctions, over reliance on under resourced consumer organizations, an "anti compliance" business culture and the lack of a sophisticated and determined consumer protection culture that is sufficiently grounded in expertise. "Culture" here is understood as a set of habits, systems of belief and values, social behaviour and tradition (Piché 2009 with further references). Finally, these various problems are exacerbated by overarching political, legislative and institutional instability.

Before developing these arguments, some introductory points should be emphasised about the approach taken. First, "enforcement" here is understood in its broad sense, as encompassing the mechanisms and rules thorough which businesses or others are held to their legally imposed responsibilities (Scott 2010).

Secondly, within this broad framework, the article differentiates public and private, individual and collective, preventive (ex ante) and corrective enforcement (ex post), and administrative, judicial and extra-judicial enforcement mechanisms. At the same time, it should be recognised how difficult it is to make clear distinctions between some forms of enforcement, especially between public and private enforcement (Cafaggi 2009). With this in mind, the paper treats public enforcement as being enforcement by public agencies and government organs, acting in the public interest and mainly conducting administrative procedures. Since in Serbia there is no single regulatory and enforcement agency that would be competent for consumer protection enforcement, public enforcement is dispersed between specialized public agencies and other government institutions with divided competences and diverging powers. Private enforcement, by contrast, is in the hands of non-governmental, 
A.Fejös, The Impact of EU Norms and Policies on Consumer Protection Enforcement in Serbia available at link.springer.com

consumer protection organizations, and individual consumers, relying on judicial and extrajudicial enforcement procedures, even though preventive actions (injunctions) commenced by private bodies (consumer protection organizations) are conducted in public interest

Thirdly, the paper is not descriptive, but analytical, seeking to identify the deficiencies in the current system of enforcement in Serbia. Therefore, the powers and duties of enforcement agents, as well as the procedural characteristics of enforcement mechanisms are not presented in full detail, but only to the extent necessary to follow the critical arguments presented.

Fourthly, the literature suggests that enforcement issues are much less related to consumer law as such, than to the economic, social and political characteristics of the given state (Micklitz 2012). A key facet of this in Serbia is that enforcement of consumer protection law has not been subject to much research. The available information is scarce and often contradictory. To bridge this gap, to a certain extent, the author relies on her own experiences, ${ }^{7}$ as well as on the information gained from other consumer protection activists, and from the employees of public agencies.

Finally, in order to better understand the paper, a brief note on the institutional framework of consumer protection enforcement in Serbia is necessary. Art. 125 CPA provides that consumer protection is the responsibility of the Ministry of Internal and External Trade and Telecommunications ("the Ministry"), consumer protection organizations, professional chambers as well as other market players. The crucial institution in shaping consumer protection policy is therefore the Ministry. The most important organizational unit within the Ministry is the Department for Consumer Protection (within the Section for Trade, Services, Prices, and Consumer Protection). This is further divided into the Division for Development of Consumer Protection Policy, responsible for creation and monitoring of consumer protection policy; and the Centre for Consumer Protection, responsible for coordination of the Advice Centres established within consumer organizations. The other large organizational unit having competence in consumer protection enforcement is the Section for Market Inspection. In addition to these various State bodies, various other institutions have important roles to play, including consumer organizations, inspectorates (other than the Section for Market Inspection), public agencies, the judiciary and consumers themselves.

\footnotetext{
${ }^{7}$ The author was a legal adviser to the Consumer Protection Association of Vojvodina (regional consumer organization for the region of Vojvodina), and member of the legal team of the National Consumers' Association of Serbia (association of consumer organizations) in the period of 2007-2012.
} 
A.Fejös, The Impact of EU Norms and Policies on Consumer Protection Enforcement in Serbia available at link.springer.com

\section{The impact of EU norms on consumer protection enforcement in Serbia}

This section will consider the implementation of EU in particular Directive 2008/52/EC on mediation, ${ }^{8}$ (Mediations Directive); the Recommendations on the principles applicable to out-of-court resolution of consumer disputes ${ }^{9}$ (Commission Recommendations); and Directive 98/27/EC on injunctions ${ }^{10}$ (Injunctions Directive). There are other more specific EU laws dealing with these issues, including Art. 7(1) Directive 1993/13/EEC on unfair contract terms ${ }^{11}$ and Art. 11(1) of Directive 2005/29/EC on unfair commercial practices: ${ }^{12}$ both of which deal with preventive control. Then there is Art. 24(1) of Directive 2008/48/EC on consumer credit $^{13}$ requiring adequate ADR scheme(s) in the credit sector. However, the focus here is on the general provisions on injunctions, mediation and out of court dispute resolution outlined above. It is argued that these EU norms have brought some formal changes to Serbian enforcement mechanisms, but without working well in practice for various reasons stemming from the fact that the mechanisms are inadequately tailored to local consumer needs.

\footnotetext{
${ }^{8}$ Directive 2008/52/EC of the European Parliament and of the Council on certain aspects of mediation in civil and commercial matters (OJ L 136, 24.5.2008).

${ }^{9}$ Commission Recommendation of on the principles applicable to the bodies responsible for out-of-court settlement of consumer disputes (OJ L 115/31, 17.4.1998) and Commission Recommendation on the principles for out-of-court bodies involved in the consensual resolution of consumer disputes (OJ L109, 19/04/2001). Most of the principles are inserted into the proposals for Directive on alternative dispute resolution for consumer disputes and amending Regulation (EC) No 2006/2004 and Directive 2009/22/EC, COM(2011) 793 final, 29.11.2011. ${ }^{10}$ Directive 98/27/EC on injunctions for the protection of consumers' interests (OJ L 166, 11.6.1998). This Directive has been later modified and codified by Directive 2009/22/EC (OJ L 110/30, 1.5.2009).

${ }^{11}$ Council Directive 93/13/EEC of 5 April 1993 on unfair terms in consumer contracts OJ L 95, 21.4.1993,

12 Directive 2005/29/EC of the European Parliament and of the Council concerning unfair business-toconsumer commercial practices in the internal market amending Council Directive 84/450/EEC, Directives 97/7/EC, 98/27/EC and 2002/65/EC and Regulation (EC) No 2006/2004, OJ L 149, 11.6.2005.

${ }^{13}$ Directive 2008/48/EC of the European Parliament and of the Council on credit agreements for consumers and repealing Council Directive 87/102/EEC OJ L 133, 22.5.2008
} 
A.Fejös, The Impact of EU Norms and Policies on Consumer Protection Enforcement in Serbia available at link.springer.com

\section{II.1. EU Norms and the Theory and Practice of Using ADR to Solve Consumer Disputes}

The Commission Recommendations on ADR lay down the general principles of independence (impartiality), transparency, effectiveness, liberty, representation, the adversarial principle and fairness. There are other requirements of accessibility, confidentiality and enforceability set by the Mediation Directive (Arts 5, 6 and 7). This section shows that, while, in theory, these EU norms are part of Serbian law, in practice accessibility and enforceability (and therefore effectiveness) are compromised because the schemes are not really designed for consumer needs, the key problems being a combination of weak sanctions and a business culture of non-compliance.

In Serbia, both arbitration (Art. 5 of Arbitration Act of 2006) ${ }^{14}$ and mediation (Art. 1 of Mediation Act of 2005) ${ }^{15}$ are potentially suitable methods of consumer dispute resolution, as they can be used for solving civil or commercial disputes save for matters which are in the exclusive jurisdiction of the courts.

Mediation is regulated by the Mediation Act of 2005 (MA), which although adopted earlier, reflects the principles of accessibility, confidentiality and enforceability required by the Mediation Directive. ${ }^{16}$ These EU norms were further embedded in Serbian consumer law when it was made explicitly clear that arbitration and mediation schemes available for general contract law disputes could be used for consumer disputes by Art. 134 CPA, in relation to mediation and arbitration in general, and by Art. 44 FSUPA in relation to mediation in financial services disputes. The problem however is that neither the mediation nor arbitration mechanisms were tailored to the resolution of consumer-business disputes.

Besides the general arbitral process (ad hoc or institutional), there are several arbitral institutions established by professional chambers and associations which in practice can be used to solve consumer disputes. These include the Courts of Honours established by the

\footnotetext{
${ }^{14}$ Zakon o arbitraži, OG RS No. 46/2006.

${ }^{15}$ Zakon o posredovanju-medijaciji, OG RS No. 18/2005.

${ }^{16}$ Arts 6, 12 and 16 of the Mediation Act.
} 


\section{A.Fejös, The Impact of EU Norms and Policies on Consumer Protection Enforcement in}

Serbia available at link.springer.com

commercial chambers ${ }^{17}$ and the specialized Court of Arbitration of the National Association of Travel Agencies $-Y U T A^{18}$ that hears claims of passengers against travel agencies.

Institutional mediation is conducted at the Centre for Mediation which has its organizational units at general courts throughout the country, save for mediation in the area of financial services, which is in the competence of the Centre for Protection and Education of Financial Services Users (CPEFSU) operated by the National Bank of Serbia (NBS). ${ }^{19}$ However, even though institutional mediation is conducted by trained mediators in line with the Program of Training for Mediators, ${ }^{20}$ according to Art. 2 of MA mediation is every procedure where the parties aim at reaching an agreement with the help of an independent third party. It is therefore possible that mediation is performed by other institutions or organizations, such as the consumer protection organizations.

In principle, the general arbitration procedure is suitable for consumer disputes, as it is flexible and relatively fast, but in practice it is not appropriate for most of the consumer disputes that involve small claims. Due to its flexibility, arbitration requires a certain degree of knowledge of arbitration and of law in general, which is unlikely for a consumer to possess. Additionally, the procedure is expensive as arbitrators charge high fees. Specialized arbitration courts might be an alternative, to the extent that they are free of all or at least some of the above deficiencies. The Arbitration Court of YUTA for example charges a small fee for deciding on a matter, and applies a simplified procedure, where consumers do not need to have previous legal knowledge or engage a lawyer. The decision is biding and enforceable, and submission to the process is obligatory for YUTA members. ${ }^{21}$ Unfortunately, the number

${ }^{17}$ Commercial Chambers Act of 2001 (Zakon o privrednim komorama), OG RS Nos. 65/01, 36/09, 99/11 (CCA). Although the Court of Honour at Belgrade Chamber of Commerce operates from 1913. See: http://www.kombeg.org.rs/Komora/EngOpsta.aspx?veza=4028 (last access: Feb. 2012). According to Art. 2 of CCA there are 19 commercial chambers. Based on Art. 30(1) of CCA Courts of Honour must be established for the Commercial Chamber of Serbia, the Commercial Chamber of Vojvodina, the Commercial Chamber of Kosovo, the Commercial Chamber of Belgrade, and may be established for the 15 remaining regional commercial chambers.

${ }^{18}$ Nacionalna asocijacija turističkih agencija - YUTA, see http://www.yuta.rs/sr/yuta/arbitraza.asp (last access: Sept. 2012).

${ }^{19}$ Centar za zaštitu i edukaciju korisnika finansijskih usluga, at http://www.nbs.rs/internet/latinica/63/index.html (last access: Feb. 2013)

${ }^{20}$ Pravilnik o programu obuke za posrednike, OG RS No. 44/05

${ }^{21}$ The details of the procedure are laid down by the Rules of Procedure of the Arbitration Court adopted by the Executive Board of YUTA. http://www.yuta.rs/sr/yuta/upravni.asp (last access: Feb. 2013). The full text of rules 
A.Fejös, The Impact of EU Norms and Policies on Consumer Protection Enforcement in Serbia available at link.springer.com

of professional organizations that have their own court of arbitration (such as that used by YUTA) is very small; therefore their importance in consumer protection enforcement is minor.

Courts of Honour established by commercial chambers are sometimes voluntarily used by consumers for dispute resolution. For example in 2008 the Court of Honour at Belgrade Chamber of Commerce handled 315 cases from which around $70 \%$ were consumer disputes. Complaints mostly related to claims arising out of non-conformity of goods and services and breach of warranty rights. ${ }^{22}$ Since the detailed rules of operation of Courts of Honours are laid down on a self-regulatory basis by commercial chambers (Art. $31 \mathrm{CCA}$ ), the procedural rules differ. In general, the procedure is free of charge, obligatory for members of the given commercial chamber, and may end with a final and binding decision. ${ }^{23}$ Nevertheless, Courts of Honour are not the most suitable for all consumer disputes. This is because the sanctions that can be applied do not necessarily provide lasting and satisfactory solutions for consumers. Courts of Honour are competent to maintain market discipline, and they primarily safeguard the observance of moral and ethical rules in business practices. ${ }^{24}$ Consequently, the sanctions are first and foremost disciplinary, in the form of different warnings and bans. It

is not available online, save for summary information at http://www.yuta.rs/sr/yuta/arbitraza.asp (last access: Feb. 2013).

${ }^{22}$ See interview with M. Kostić-Ćosić the Secretary of the Court of Honour at Belgrade Chamber of Commerce in 2009, available at http://www.youtube.com/watch?v=1QF_GryuQ6Y (last access: Feb. 2013). The Court of Honour at the Commercial Chamber of Serbia had significantly less cases. In 2012 the total number was 17 from which 8 consumer complaints (information on the nature of the claim is not available). In 2011 from 22 submitted cases 13 were filed by consumers for breach of contract by the business. Information Booklet o the Operation of the Commercial Chamber of Serbia (Informator o radu Privredne komore Srbije), January 2013, p. 46-47 available at http://www.pks.rs/Informator1.pdf (last access: Jan. 2013).

${ }^{23}$ Based on the two Rulebooks publicly available it can be said the decisions of the Courts of Honour are final and biding if it acts as a second instance organ, and if the limitation period lapsed if it acts as a first instance organ. See Arts. 81\&93 of the Rulebook of the Court of Honour at the Commercial Chamber of Serbia (Pravilnik o Sudu časti pri Privrednoj komori Srbije, OG RS No. 39/2006) and Art. 82 of the Rulebook on the organization, composition and operation of the Court of Honour by the Commercial Chamber of Belgrade (Pravilnik o organizaciji, sastavu i radu Suda časti pri privrednoj komori Beograda, Official Journal of the City of Belgrade Nos. 16/03, 6/09).

${ }^{24}$ The ethical rules are laid down in the Code of Business Ethics (Kodeks poslovne etike, OG RS 1/06). The Code is mandatory for commercial entities, members of commercial chambers and their employees (Art. 1). 


\section{A.Fejös, The Impact of EU Norms and Policies on Consumer Protection Enforcement in} Serbia available at link.springer.com

follows that the court cannot force the business to perform the contract or to pay damages to the consumer.

Turning now to mediation, in practice, most consumers will be directed by consumer organizations and financial service providers to solve their disputes either at the Centre for Mediation or the CPEFSU. However, even though mediation provides fast, accessible and in most cases free of charge dispute resolution, ${ }^{25}$ it is not very suitable for consumer disputes because it requires the cooperation of the business party and therefore does not necessarily provide a solution if businesses refuse to cooperate. The same problem applies to any mediation outcome, which is dependent on an agreement between the parties before it can be endorsed by a court under Art.16 MA. ${ }^{26}$ However, the initial process of mediation may only be commenced in the first place when there is an agreement between the parties. In practice there appears to be an anti-compliance culture amongst businesses who often disregard the consumer's initiation of the dispute, and do not act upon the consumer's request to go to mediation. ${ }^{27}$ Consequently, even though the Centre for Mediation claims to have a success rate of $83 \%,{ }^{28}$ these statistics are only based on those mediations that businesses have agreed to participate in the first place.

The same problem arises in the area of financial services where mediation is conducted by the CPEFSU. Again, there is a tendency for operators not to agree to participate in the first place. However, even when they do participate, there seems to be a lower

\footnotetext{
${ }^{25}$ From July 2012 mediation at the Centre for Mediation for small value consumer disputes is free of charge. See: http://www.medijacija.rs/post/show/3 (last access: Sept. 2012). Mediation in the area of financial services is also free of charge, however, the process is conducted only in Belgrade, at the premises of NBS and therefore it might trigger some expenses.

${ }^{26}$ Art. 10 MA; Point 14 Decision of NBS on the ways of complaint handling by banks and financial leasing providers, and the activities of NBS upon the notification of complaints by users (Odluka o načinu postupanja banke i davaoca lizinga po prigovoru korisnika finansijskih usluga i načinu postupanja Narodne Banke Srbije po obaveštenju tih korsnika), OG RS No. 65/2011.

${ }^{27}$ The author it thankful for informal conversations on this point with consumer protection activists at the Association of Consumers of Serbia (Asociajacija potrošača Srbije) and the Consumers Center of Serbia (Centar potrošača Srbije) taken place in March 2012, and July 2012 respectively.

${ }^{28}$ No data is available on the nature and issues involved. See: http://www.medijacija.rs/rezultati (last access: Sept. 2012).
} 


\section{A.Fejös, The Impact of EU Norms and Policies on Consumer Protection Enforcement in Serbia available at link.springer.com}

willingness to settle compared to general mediation, with the statistics showing a success rate of around $50 \% .^{29}$

It is worth highlighting that the legal system of Serbia also has an ombudsman, but it has no general competence that would make it suitable to solve business to consumer disputes. According to Art. 1 of the Protection of Citizens Act of $2005^{30}$ the Protector of Citizens (Ombudsman) protects the rights of citizens, promotes human and minority rights, and controls the operation of the public administration and public undertakings. Following the example of Hungary, ${ }^{31}$ the Ombudsman probably could establish competence to control the activities of the state owned enterprises providing services of general interest, but there is no evidence of such practice. ${ }^{32}$ However, the Ombudsman is not an enforcement agent that would provide a viable solution for business-to-consumer disputes as it has no legally binding and enforceable powers. The principal tool of the Ombudsman is a recommendation which has no mandatory binding force, but depends on voluntary compliance, a serious deficiency given the anti-compliance culture of Serbian businesses. It is not surprising then that the Ombudsman has had limited success. ${ }^{33}$

\footnotetext{
${ }^{29}$ The majority of complaints (more than $85 \%$ ) relates to the operation of banks, to credit, current account or payment cards. For example in 2011 from the total of 1885 complaints, out of which 1122 was admissible, 885 (84.8\%) were against the banks, 237(13.3\%) insurance companies, 27 (1.6\%) finance lease companies, 2 $(0.11 \%)$ voluntary pension funds. In 2011 the success rate of mediation was $46 \%$. Report on the activities of
} CPEFSU January-December 2011 (Izvestaj o radu centra za korsnike finansijskih usluga januar-decembar 2011), at http://www.nbs.rs/export/sites/default/internet/latinica/63/63_8/izvestaj_januar_decembar_2011.pdf (last access: Feb. 2013). In 2010 from the total of $106680 \%$ of complaints was directed towards banks, from which 311 were admissible and 161 or $53 \%$ successfully mediated. See: Report on the activities of CPEFSU JanuaryDecember 2010 (Izveštaj o radu centra za korisnike finansijskih usluga za januar-decembar 2010), at http://www.nbs.rs/export/sites/default/internet/latinica/63/63_8/izvestaj_januar_decembar_2010.pdf (last access: Feb. 2013).

${ }^{30}$ Zakon o zaštitniku građana of 2005, OG RS Nos. 79/05, 54/07.

31 See A. Dezső and others, The Financial Law Project of the Parliamentary Commissioner for Civil Right, November 2011, at: http://www.obh.hu/allam/eng/index.htm (last access: Feb. 2013).

${ }^{32}$ Information Booklet of the Protector of Citizen for 2008-2013 (Zaštitnik građana Repulbike Srbije Informator o radu 2008-2013), Belgrade, 2013, at: http://www.ombudsman.rs/index.php/langsr/component/content/article/132 (last access: Feb. 2013).

${ }^{33}$ In the period of 2007-2012 from the total of 11694 completed initiatives the PC initiated 4367 investigations, in 1154 cases the organs corrected the irregularities during the processes itself without a need for recommendation; the PC issued 1102 recommendations from which 692 (62,79\%) were complied with, 247 (22.41\%) were not complied with and 163 (14.79\%) are still pending. In the same period the PC had 149 
A.Fejös, The Impact of EU Norms and Policies on Consumer Protection Enforcement in Serbia available at link.springer.com

To sum up, the above discussion shows that the various ADR schemes, particularly mediation, are generally in line with key EU norms, including accessibility and perhaps enforceability, but in practice there are very serious deficiencies. Of course, practical enforcement problems will always be partly caused by lack of awareness by consumers of their rights and of the available dispute resolution mechanisms. Another possible factor may be a cultural tendency of Serbian people to feel "ashamed" to complain or to admit that they have been a victim of "foul play". ${ }^{34}$ However, the really key distinctive factors undermining practical effectiveness have been weak sanctions and the presence of an anti-compliance business culture. It has been suggested that the latter is possibly connected to a Serbian mentality of being stubborn in pursuing one's own conception of "justice" thereby making it difficult to reach compromise (Kovačević 2006).

\section{II.2. Using Injunctions for the Protection of Consumers}

The Injunctions Directive was implemented into Arts. 137-146 CPA. The procedural rules have been further concretised by the Civil Procedure Act of 2011 (CPRA). ${ }^{35}$ The CPRA introduced a new procedure, the Procedure for the protection of collective rights and interests of citizens (Arts. 494-505 CPRA). The procedure is to be used for solving deputes arising from unfair commercial practices and unfair contract terms. Legal standing is vested in consumer protection organizations and their associations (Art. 495 CPRA; Arts. 129\&137CPA) and individual consumers (Art. 505 CPRA; Art. 137 CPA). Therefore, injunctions are suitable for both individual and collective disputes resolution. Consumer organizations and their associations can represent consumers in individual actions (Art. 130 CPA).

There are several problems related to this type of enforcement, including a variety of general procedural problems as well as specific problems related to the fact that only consumer organizations have standing to seek injunctions.

\footnotetext{
legislative initiatives, $40(26.85 \%)$ were accepted, $100(67.11 \%)$ not accepted and 9 are pending (6.04\%). See above

${ }^{34}$ The author is thankful for this insight to the activist of the Association of Consumers of Serbia given in an informal conversation in July 2012.

${ }^{35}$ Zakon o parničnom postupku, OG RS No. 72/11.
} 
A.Fejös, The Impact of EU Norms and Policies on Consumer Protection Enforcement in Serbia available at link.springer.com

In relation to general procedural drawbacks, neither the CPRA nor the CPA provides any exception regarding the fees and expenses of the procedure when the proceedings are initiated by consumer organizations. Additionally, the CPRA now provides that the representatives of parties can only be lawyers (Art. 85 CPRA), which raises the cost of the procedure. Even though the rule is that the losing party pays all the expenses, since the outcome is uncertain, as judges may often be reluctant to decide against powerful businesses, especially monopolistic enterprises, and the expenses due during the process can be substantial, having no exception in favour of consumer organizations is a deterrent factor to represent consumers in judicial actions. Moreover, if the dispute ends with judicial settlement, each party bears their own expense, which is again a negative incentive for consumers, including an incentive not to settle (Art. 158 CPRA). Another general procedural problem is that in the procedure for collective actions no damages can be claimed, damages are awarded in a separate procedure according to general rules of civil procedure.

An additional limitation is due to the absence of special rules regarding the effects of the judgement. According to the general rules, the judgement relates only to a specific claim and a specific defendant having effect only between parties to the dispute (Art. 342-343 CPA). Therefore, the judgement rendered in one case will not extend to another, regardless of the similarity of subject matter. However, there is potential for a limited effect towards third parties, as after declaring the term null and void, the court might order the business to discontinue the use of an unfair term in contracts that will be concluded in the future. Therefore, injunctions can be an effective corrective enforcement tool, though depending on the judge's discretion. However, they do not provide a desirable corrective solution in case of unfair contract terms, as the judgement does not touch upon already concluded contracts not subject to the dispute.

The second key problem is that under Art. 137 CPA only consumer organizations have standing to represent the collective interests of consumers in judicial actions. However, these organizations are seriously lacking in both funding and expertise.

Consumer protection organizations are non-profit and non-governmental, independent organizations created based on the Associations Act of 2009. ${ }^{36}$ They usually have a separate legal personality, but this is not a necessary requirement for their establishment (Art. 2 Associations Act). The total number of consumer organizations in Serbia is $74 .^{37}$ However,

\footnotetext{
${ }^{36}$ Zakon o udruženjima, OG RS No. 51/09

${ }^{37}$ See: http://www.zastitapotrosaca.gov.rs/udruzenja.php (last access: Feb. 2013).
} 
A.Fejös, The Impact of EU Norms and Policies on Consumer Protection Enforcement in Serbia available at link.springer.com

not all are empowered to represent the collective interests of consumers. Only the organizations that have the necessary manpower and professional expertise can represent the collective interests (Art. $130 \mathrm{CPA}$ ).

The Ministry registers and keeps records of consumer organizations (Art. 129 CPA) based on Rules on the Records of Consumer Organizations and Associations of Consumer Organizations of 2011 (Rules), ${ }^{38}$ of which there are currently $26 .{ }^{39}$ All registered organizations have general competence, with the exception of one that specializes in protecting banking clients, the Association of Banking Clients Efektiva ("Efektiva"). ${ }^{40}$ Most of the organizations' activities are limited locally or regionally. However, in practice, the institutions that are most important in creation and enforcement of consumer protection law and policy in Serbia are the associations of consumer organizations. These are: the National Consumers' Protection Organization (22 member organizations); ${ }^{41}$ the Association of Consumers of Serbia (5 member organizations); ${ }^{42}$ the Consumers' Centre of Serbia (13 member organizations). ${ }^{43}$ These are the organizations that operate the Advice Centres, they are represented in the National Council of Consumer Protection, and they are seen as project partners by the Ministry. ${ }^{44}$ However, the associations of consumer organizations should not be thought of as massive organizations. In practice they are themselves run by a small number of people, that often lack professional education, or some see consumer activism as a "second job" being employed elsewhere. A small number of professionals usually work pro bono and voluntarily.

The professionalization of consumer organizations radically improved in 2010 with the establishment and government funding of the Advice Centres. The Advice Centres are primarily in place to advise consumers on their rights and to give information on available redress mechanisms, where the advice is given by a lawyer (with or without bar exam). Since

\footnotetext{
${ }^{38}$ Pravilnik o evidenciji udruženja i saveza udruženja za zaštitu potrošača, OG RS No. 32/11

${ }^{39}$ http://www.zastitapotrosaca.gov.rs/evidentirana-udruzenja.php (last access: Feb. 2013)

${ }^{40}$ Udruženje Bankarskih Klijenata Efektiva at www.efektiva.rs (last access: Feb. 2013)

${ }^{41}$ Nacionalna Organizacija Potrošača Srbije at www.nops.org.rs. For members see: http://www.nops.org.rs/cms/index.php?id=40 (last access: Feb. 2013)

${ }^{42}$ Asocijacija postoršača Srbije, www.apos.org.rs, for members see: http://www.apos.org.rs/cms/index.php/sr/onama-mainmenu-35/373-clanice-apos-a.html (last access: Feb. 2013)

${ }^{43}$ Centar potrošača Srbije www.ceps.rs; for members see: http://www.ceps.rs/lanice-ceps-a.html (last access:
} Feb. 2013)

${ }^{44}$ See: http://www.zastitapotrosaca.gov.rs/evidentirana-udruzenja.php (last access: Feb. 2013) 


\section{A.Fejös, The Impact of EU Norms and Policies on Consumer Protection Enforcement in Serbia available at link.springer.com}

there are only four Advice Centres in place for the entire country, and as consumer awareness is rising, the Advice Centres are overburdened with complaints. ${ }^{45}$ It follows that even though the lawyers could provide court representation, they either lack experience or time. In the past two years, consumer organizations in total represented consumers in two individual judicial actions and one ADR process. ${ }^{46}$

Even though the registration of consumer organizations was likely intended to raise their level of professionalism and to prevent over-creation, in practice registration did not reach the set aims. The criteria for registration are intended to ensure appropriate levels of expertise. However, in practice, consumer organizations satisfy the conditions only on paper, formally signing up experts to help, but in practice not making sufficient use of their services. ${ }^{47}$ Consumer organizations do not have financial resources to externally engage practicing lawyers. So far the government has financed only lawyers that would work in the Advice Centres, and there is no additional financing for litigating lawyers. In addition, in Serbia, in the author's experience, lawyers do not tend to work pro bono. Alternative financing, such as insurance is not available, probably due to Serbia's underdeveloped financial market. As a result, consumer organizations lack the sufficient expert manpower to take up and pursue complex cases.

Therefore, a key reason for the lack of expertise and professionalism stems from the lack of funding. Consumer organizations do not have stable and constant government funding but the government funds the organizations on the basis of projects. The author's own research has revealed that, save for one, consumer organizations do not seem to have open membership, and therefore income from membership fees.

The work of the specialized organization Efektiva deserves special attention. Efektiva is one of the youngest consumer organizations in Serbia, established in 2011, but already appears to show better results than some organizations after ten years of operation. It has clear

\footnotetext{
${ }^{45}$ In 2011 the Advice Centres received a total of 6634 consumer complaints, while in 2010 the aggregate number of claims was 2347 complaints. The majority of complaints related to non-conformity of goods and services (in 2011626 claims or 26.67\%) and breach of warranty rights (in 2011726 claims or 30.93\%). See: A comparison of consumer complaints in 2010 and 2011 (Uporedni prikaz broja potrošačkih prijava u 2010 and 2011. godini) at: http://www.zastitapotrosaca.gov.rs/CMS/izvestaji/uporedni-prikaz-broja-potrosackih-prijava-u-2010-i-2011godini.pdf (last access: Feb. 2013).

${ }^{46}$ Ibidem

${ }^{47}$ This is based on the authors own experience, confirmed by the activist of the Association of Consumers of Serbia in an informal conversation in July 2012.
} 
A.Fejös, The Impact of EU Norms and Policies on Consumer Protection Enforcement in Serbia available at link.springer.com

policy objectives, transparent funding and membership. In turn for a membership fee it gives credit advice and offers free of charge court representation. ${ }^{48}$ It seems that Efektiva has a different "business model" than the other organizations in Serbia, which primarily rely on project financing and funds from the Government, and do not render professional services. Probably due to its different funding structure Efektiva had the necessary resources to file the first collective action in February 2013 against three banks for unilateral amendments of the fixed part of the interest rate and for selling mortgage loans indexed in Swiss Francs. ${ }^{49}$

In conclusion, since the CPA entrusted the collective enforcement of consumer rights only to consumer organizations, which are under-staffed and under-resourced, there is a danger that in practice the preventive and collective protection of consumers will be ineffective.

\section{The impact of EU policies on the consumer protection enforcement framework}

Besides the impact of EU norms on consumer protection in Serbia as considered above, we now turn to how the broader enforcement framework fits into the general EU policies. The general EU requirement for the protection of consumer, or other interests under EU law is that legal protection should be effective and appropriate (Reich 2009 p. 310). This requirement is also laid down in Art. 78 SAA; according to which effective consumer protection can be achieved by a solid administrative infrastructure that ensures market surveillance and by effective law enforcement. This section will further demonstrate that effective protection is not achieved due to weak sanctions, the absence of a sophisticated and determined consumer protection enforcement culture that is sufficiently well grounded in expertise, as well as broader legislative, institutional and political instability.

\section{III.1. Insufficient Sanctions Available to Administrative Agencies}

Administrative agencies or agencies with public powers are part of the public administration in Serbia, and according to Public Administration Act of 2005 (PADA), ${ }^{50}$ in exercising their duties agencies have the same powers as the public administration (Art. 51

\footnotetext{
${ }^{48}$ No available data on the number of members: www.efektiva.rs (last access: Feb. 2013).

${ }^{49}$ See: http://efektiva.rs/aktuelnosti-krediti/saopstenje-medijima (last access: Feb. 2013)

${ }^{50}$ Zakon o državnoj upravi, OG RS Nos. 79/2005, 101/2007, 95/2010.
} 


\section{A.Fejös, The Impact of EU Norms and Policies on Consumer Protection Enforcement in} Serbia available at link.springer.com

PADA). According to the Act on Public Agencies of 2005 (PAGA) ${ }^{51}$ public or administrative agencies are established to adopt acts of secondary law for enforcing the legislative acts (regulatory tasks), to resolve disputes (enforcement tasks), to issue licenses and maintain databases (administrative tasks). The agencies are separate legal persons (Art. 5 PAGA) and should be politically and financially independent from their founder (Arts. 4 PAGA). Supervision of agencies is vested in the ministry, whose tasks are entrusted to the agency (Art. 44- 46 PAGA).

There are a large number of public agencies in the Serbian legal system (Aleksić 2012), but only a small number of those directly operate in the sphere of consumer protection. Enforcement by public agencies is especially common in the area of public utility services. The most important agencies are the Energy Agency of the Republic of Serbia (EARS) established by the Energy Act of 2004 (EA) in $2005^{52}$ responsible for public utility services in electricity, natural gas, oil and oil products, and heating energy; and the National Agency for Electronic Communications (NAEC) regulated by the Electronic Communications Act of $2010(\mathrm{ECA})^{53}$ established in $2005^{54}$ with competence in the area of electronic communications, primarily telecommunications and internet services. NAEC also accepts consumer complaints in connection with television and radio broadcasting. ${ }^{55}$

Though public agencies play an important role in the system of consumer protection in Serbia, their potential is rarely fully realised. Although the agencies can impose some sanctions, such as the withdrawal of a licence (e.g. Art. 95 ECA), they have no sufficient powers for consumer protection enforcement. The real power of agencies, the power to impose penalties is not applicable for cases of consumer complaint handling or breaches of consumer rights. Upon the compliant of the consumer, in practice the agencies attempt to mediate between the service provider and the consumer, aiming to persuade the service

\footnotetext{
${ }^{51}$ Zakon o javnim agencijama, OG RS Nos. 18/2005, 81/2005

${ }^{52}$ Zakon o energetici, OG RS No. 84/04, repealed by Energy Act of 2011 OG RS Nos. 57/11, 93/12. See: Agencija za energetiku Republike Srbije at http://www.aers.rs/ (last access: Sept. 2012).

${ }^{53}$ Zakon o elektronskim komunikacijama, OG RS No. 44/10. See: http://www.ratel.rs/home.136.html (last access: Sept. 2012).

${ }^{54}$ As a successor of the National Agency for Telecommunications, established by Act on Telecommunications (Zakon o telekomunikacijama), OG RS Nos. 44/93, 36/06, 50/09.

${ }^{55}$ Even though there is a separate agency, the National Broadcasting Agency (Repulička radiodifuzna agencija) for regulation and supervision of television and radio operators, all consumer complaints are handled by the NAEC. This information is communicated to the author by an employee of the agency by e-mail dated Feb. 3, 2012.
} 


\section{A.Fejös, The Impact of EU Norms and Policies on Consumer Protection Enforcement in Serbia available at link.springer.com}

provider to render a decision, and to respect the rights of consumers under the law by relying only on their authority (Arts. 46 EA; Art. 113 ECA). But if the service provider fails to answer the consumer's complaint, or renders a negative decision, the agencies can only notify the competent inspectorate (Arts. 181-190 EA; Arts. 131-136 ECA) or commence a misdemeanour procedure before the courts (Arts. 192-193 EA; Art. 138 ECA), but they cannot directly impose fines. ${ }^{56}$ This lack of competence stems from the limit imposed by Art. 137 of the Constitution of the Republic of Serbia of $2006^{57}$ that sees public agencies as regulatory bodies. Consequently, the enforcement function of public agencies comes down to first instance dispute resolution between the service provider and the consumer. By having a look at the success rate of complaint handling, on can notice that the powers the agencies have, or their authority, is not a sufficient deterrent factor for service providers. ${ }^{58}$

Therefore, it seems that both preventive and corrective enforcement by public agencies is insufficient; with too much emphasis on their regulatory and administrative function at the expense of the enforcement function. A key reason for the weakness of enforcement activity is the insufficient power of agencies to impose sanctions.

A special form of public agency is the Commission for the Protection of Competition (CPC) established in 2005 and regulated by the Act on the Protection of Competition of 2009 (ACP). ${ }^{59}$ The CPC, accountable only to the National Parliament (Art. 20 ACP), enjoys the largest degree of political independence (Beljanski 2008). In contrast, the above mentioned agencies are open to significant political influence (Beljanski 2008). Moreover, the CPC is solely financed from independent sources, i.e. from the services it renders (Art. 31 ACP). Although fines for competition infringement are payable to the state budget (Art. 57 ACP), the

\footnotetext{
${ }^{56}$ The author is grateful for help on this point to the activist of the Consumers Association of Serbia. The informal conversation took place in March 2013.

${ }^{57}$ Ustav Republike Srbije No. 98/06.

${ }^{58}$ In 2009 the NAEC received 385 complaints from which 110 or $28.5 \%$ have been positively solved; in 2010 the ratio was 465 to 75 , which amount to approx. $16 \%$ of positively solved complaints. Information booklet, January 2012, p. 16-17, available at:

http://www.ratel.rs/upload/documents/O_Ratelu/Plan_rada/INFORMATOR_jan_2012.pdf (last access: 10. Feb. 2012). The EA in 2011 received 47 complaints as a first instance organ, and 112 complaints as a second instance organ, however, there is no information on the success of the complaints. Information Booklet on the Activities of EA (Informator o radu Agencije za energetiku Republike Srbije), Belgrade, December 2012, p. 24-25 available at: http://www.aers.rs/Index.asp?1=1\&a=17 (last access: Feb. 2013).

${ }^{59}$ Zakon o zaštiti konkurencije OG RS No. 51/2009 repealing Zakon o zaštiti konkurencije, OG RS No. 79/05.
} 


\section{A.Fejös, The Impact of EU Norms and Policies on Consumer Protection Enforcement in Serbia available at link.springer.com}

CPC retains revenues for rendering decisions on concentration clearances and decisions on exceptions from restrictive agreements that represent constant and significant funding sources for the CPC.

The CPC has been accorded more significant enforcement powers compared to other public agencies in Serbia. It has significant investigative powers (Art. 52 ACP), and, more importantly, it can directly impose fines on businesses (Art. $68 \mathrm{ACP}$ ). At its establishment, the $\mathrm{CPC}$ was powerless to impose direct fines and like other agencies had to resort to the misdemeanour courts to actually impose the fine determined. Courts however, instead of enforcing, annulled the decisions of the CPC. As a result, in the first five years of operation no fine was imposed for the violation of competition by the CPC (Radojević 2010). At the end of 2009 the new ACP came into force that granted this enforcement power, and already in 2010 the CPC issued two fines. ${ }^{60}$ Therefore, the primary reason that hindered the efficiency of the CPC was the lack of power to directly impose fines (Radojević 2010). Unfortunately, the CPC has no direct powers to enforce consumer protection regulation.

\section{III.2. The case of the Inspectorates}

Enforcement by inspectorates is the traditional public enforcement tool in Serbia. Inspectorates are part of the public administration, and according to Art. 18 PADA they are in place to control the lawfulness of the activities of natural and legal persons and, depending on the results of such controls, order different measures within their competence. Inspectorates are established within sectoral ministries, with centralized control and coordination, and complicated internal structure. ${ }^{61}$ Currently there are 33 inspectorates within 14 ministries. ${ }^{62}$

\footnotetext{
${ }^{60}$ Annul Report on the Activities of the Commission for the Protection of Competition for 2010 (Godišnji izvštaj o radu Komisije za zaštitu konkurencije za 2010. god), p. 12 at http://www.kzk.org.rs/kzk/wpcontent/uploads/2011/08/GODISNJI-IZVESTAJ-O-RADU-KZK-2010.pdf (last access: Feb. 2013).

${ }^{61}$ For example the Department of Market Inspection is responsible to observe the application of the law connected to trade in goods and services, and commercial practices, established within the Ministry. Certain sectors primarily those responsible for oversight and coordination are located within the Ministry, while the majority of departments (24) are located throughout the country. See: http://razvoj.mtt.gov.rs/sektori/grafickiprikaz-organizacione-strukture-sektora-trzisne-inspekcije/ (last access: Feb. 2013).

${ }^{62}$ Nikola Selaković (Minister of Justice and Public Administration) at VI European legal and political forum: "How can inspectorates protect the citizens of Serbia and its economy" (VI Evropski pravni i politički forum na temu "Kako inspekcije mogu zaštititi građane Srbije i ekonomiju?) held on April 5, 2013 reported by RTS:
} 
A.Fejös, The Impact of EU Norms and Policies on Consumer Protection Enforcement in Serbia available at link.springer.com

Inspection is conducted by inspectors, public officials, who are, as public servants according to Art. 3 Public Servants Act of 2005 (PSA), ${ }^{63}$ employees of the state. The necessary conditions for appointment are citizenship, good moral standing and university education (Art. 45 PSA). Inspectors are independent in the execution of their powers, and are personally responsible for the actions taken (Arts. 5-6 PSA). Inspectors are especially liable for failing to order a measure within their powers during control, failing to initiate the appropriate judicial or administrative action for the breach of law and for the excess of powers (Tomić 2009, p. 226). Besides being responsible for criminal and misdemeanour offences, as public servants inspectors are bound by disciplinary and material liability (responsibility for damages). One of the disciplinary measures is discharge from appointment (Art. 110 PSA).

Control of public servants is entrusted to the Administrative Inspectorate, established by the Administrative Inspectorate Act of $2011^{64}$ within the Ministry of Justice and Public Administration. It is a separate inspectorate competent only to control the work of public officials, including inspectors, the legality and transparency with respect to certain statutes such as the laws on public administration, on administrative procedure, and on public servants. The practical role of Administrative Inspectorate is at the time of finalizing the paper uncertain. ${ }^{65}$ However, the control in the substance of individual decisions, and the observance of specific acts like the CPA, remains in the competence of sectoral ministries. For example the decision of an inspector belonging to the Market Inspectorate can be appealed to the Minister of Trade and Telecommunications (Art. 150 CPA).

The work of inspectorates is regulated by more than 1000 laws and by-laws. ${ }^{66}$ It is therefore difficult to generalize, but inspectors may have a power to inspect (documents and

http://www.rts.rs/page/stories/sr/story/125/Dru\%C5\%A1tvo/1299032/Ure\%C4\%91enje+oblasti+inspekcijskog+ nadzora.html (last access: May 2013).

${ }^{63}$ Zakon o državnim službenicima, OG RS Nos. 79/2005, 81/2005, 83/2005, 64/2007 67/2007, 116/2008, $104 / 2009$.

${ }^{64}$ Zakon o upravnoj inspekciji, OG RS 87/11.

${ }^{65}$ The Administrative Inspectorate was established near the end of 2012, therefore the Information Booklet on the Operation of the Administrative Inspectorate from March 7, 2013 contains no data on achieved results. See: Informator o radu Upravnog inspektorata Ministarstva pravde i državne uprave at http://www.drzavnauprava.gov.rs/article.php?id=21 (last access: May 2013)

${ }^{66}$ The words of Nikola Selaković Minister of Justice and Public Administration at VI European legal and political forum on the topic: "How can inspectorates protects the citizens of Serbia and its economy" (VI Evropski pravni i politički forum na temu "Kako inspekcije mogu zaštititi građane Srbije i ekonomiju?) held April 5, 2013 reported by RTS: 


\section{A.Fejös, The Impact of EU Norms and Policies on Consumer Protection Enforcement in Serbia available at link.springer.com}

premises); to conduct hearings and take statements; to take samples and other objects for analysis and expertise; to order measuring; to order measures (preventive and corrective); to order fines; to notify criminal offences and to initiate misdemeanour proceedings; to issue warnings and prohibitions; to order security measures in case of danger for the life and health of people (Stanojev 2009). The powers of inspection therefore may be directed towards preventive, corrective or repressive measures (Dimitrijević 1983, p. 279).

A large number of inspectorates are competent to enforce consumer law. However, as the rights, duties and powers of inspection are not laid down in one legislative act, the powers of this institution vary depending on the area of consumer protection. For example according to the CPA market inspectors are competent to issue warnings, eventually to impose a temporary ban on business activity, and commence a misdemeanour procedure (Arts. 149,151 CPA). But, under Art. 121 of the Tourism Act of $2009,{ }^{67}$ besides the right to commence misdemeanour procedures, inspectors are also competent to issue on the spot fines for irregularities they find during inspection. Based on Art. 135 of the ECA, inspectors may seize goods and equipment.

While potent on paper, the principal problem with this enforcement mechanism is that, despite the accountability mechanisms in place, inspectors often fail to act. Inspectors may act on their own initiative within regular surveillance activity, and upon the report of natural and legal persons. However, in practice it is difficult to reach the inspection to report a violation of the law. Additionally, the inspector has no obligation to report information on the measures that have been taken. Moreover, though inspectors have an obligation to act, the issue of whether there was a breach is often left to the interpretation of the inspector. ${ }^{68}$ Finally, often, even if inspectors notice irregularities, they stay passive. ${ }^{69}$

http://www.rts.rs/page/stories/sr/story/125/Dru\%C5\%A1tvo/1299032/Ure\%C4\%91enje+oblasti+inspekcijskog+ nadzora.html (last access: May 2013).

${ }^{67}$ Zakon o turizmu, OG RS Nos. 36/2009, 88/2010.

${ }^{68}$ For example under Art. 148 CPA the inspector will decide whether the business acted against the provisions of the CPA on unfair commercial practice, but inspectors have a large leverage in deciding whether the practice in question was an unfair commercial practice.

${ }^{69}$ In the second half of 2012 the local inspections within the Market Inspectorate conducted 28.224 inspections. A total of 2.754 actions have been initiated based on the notification of inspectors (2.685 misdemeanour procedures, 68 economic offences, and 1 to the court of honour). The total of 3.650 administrative measures were ordered (1.025 measures of temporary ban on trade in different goods or services; 1.879 decisions for correction of irregularity, 617 decisions on cessation of goods, 7 decisions on closure of business, 9 decisions for 
A.Fejös, The Impact of EU Norms and Policies on Consumer Protection Enforcement in Serbia available at link.springer.com

In practice, consumer organizations in their work most often come across the Market Inspectorate, the Telecommunications Inspectorate, and the Sanitary, Phytosanitary and Veterinary Inspectorate. The first lacks competence, the second manpower, and the third legal basis to act. ${ }^{70}$ Therefore, the question why inspectors are passive may have more than one answer. Sometimes they lack the necessary legal training to conduct administrative procedures (N. Tomić 2003); at other times they lack sufficient expertise to detect irregularities (Milovanović 2009), or resources in terms of equipment and manpower (N. Tomić 2003). Further, a very significant reason stems from the large number of laws that often contradict one another (Milovanović 2009). Finally, different forms of corruption are also present (Milovanović 2009). ${ }^{71}$

Apart from any corrective role, the preventive function of the institution which should introduce market discipline is also absent (Milovanović 2009). Only $15 \%$ of traders have said to have good cooperative relationship with the inspectors. ${ }^{72}$

Currently there is a discussion on the reform of inspectorates, but there is no agreement on how this reform should look like. The question is whether to merge the 33 inspectorates into a General Inspectorate or rather leave the system as it is, within sectoral ministries but connect and coordinate their work. Besides institutional reform, the discussion

non-compliance with minimal conditions for the start of business operation, and 113 other decisions).

Information Booklet of the Ministry of Internal and External Trade and Telecommunications (Informator o radu Ministarstva spoljne i unutrašnje trgovine i telekomunikacija), December 2012, available at:http://razvoj.mtt.gov.rs/download/informator-o-radu/informator_o_radu mtt 2012.pdf (last access: Feb. 2013). The data does not indicate which actions were initiated based on the CPA. Also, since no data from previous years is available it is difficult to observe any trends.

${ }^{70}$ The author is grateful for help on this point to the activists of the Association of Consumers of Serbia in May 2013.

${ }^{71}$ The existence of corruption is also confirmed at VI European legal and political forum on the topic: "How can inspectorates protects the citizens of Serbia and its economy" (VI Evropski pravni i politički forum na temu "Kako inspekcije mogu zaštititi građane Srbije i ekonomiju?) held April 5, 2013 reported by RTS: http://www.rts.rs/page/stories/sr/story/125/Dru\%C5\%A1tvo/1299032/Ure\%C4\%91enje+oblasti+inspekcijskog+ nadzora.html (last access: May 2013).

72 The words of the Vice-President of the Commercial Chamber of Serbia Vidosava Dzagic said at VI European legal and political forum on the topic: "How can inspectorates protects the citizens of Serbia and its economy" (VI Evropski pravni i politički forum na temu "Kako inspekcije mogu zaštititi građane Srbije i ekonomiju?) held April 5, 2013 reported at http://www.euractiv.rs/srbija-i-eu/5674-srbiji-potreban-novi-zakon-o-inspekcijama(last access: May 2013). 


\section{A.Fejös, The Impact of EU Norms and Policies on Consumer Protection Enforcement in} Serbia available at link.springer.com

also includes a need for a new act that will clarify and if possible unify the procedure of surveillance, the powers of inspectors, and the rights and obligations of subjects of surveillance. It seems the current government sees inspectorates crucial in creation of a modern state that is based on the rule of law, and set the reform of inspectorates as one of its priorities. ${ }^{73}$ It remains to be seen how far the reform will go, and how soon results will be seen.

\section{3. Some Additional Problems}

Besides the various causes outlined above, the failure of enforcement in Serbia is arguably exacerbated by the overarching political, legislative and institutional instability. The Serbian Government is characterised in general by not having a clear regulatory strategy or a consistent plan for the future. Reforms instituting radical changes are frequent, but are often done without thinking through the consequences, and are possibly overseen by incompetent people. For example since the year of 2000, the change of political regime and the start of comprehensive political and economic reforms, a number of public agencies have been created (Šuput 2009). Their creation was encouraged by the Strategy for the Reform of Public Administration in the Republic of Serbia $;{ }^{74}$ and has been seen as a positive characteristic of modern societies (Tomić 2009, p. 172). However, in current attempts to rationalize public spending, the government has closed down a number of agencies, some of which might have been working well. In addition, the closures are often not carried out based on any transparent criteria (Aleksić 2012). ${ }^{75}$ Probably in line with rationalizing public spending, the Division for

\footnotetext{
${ }^{73}$ Announced by Nikola Selaković Minister of Justice and Public Administration VI European legal and political forum on the topic: "How can inspectorates protects the citizens of Serbia and its economy" (VI Evropski pravni i politički forum na temu "Kako inspekcije mogu zaštititi građane Srbije i ekonomiju?) held April 5, 2013 reported by RTS:

http://www.rts.rs/page/stories/sr/story/125/Dru\%C5\%A1tvo/1299032/Ure\%C4\%91enje+oblasti+inspekcijskog+ nadzora.html (last access: May 2013).

${ }^{74}$ Strategija reforme državne uprave u Republici Srbiji, Nov. 2004, available at: http://www.region.vojvodina.gov.rs/index.php?option=com content\&view=article \&id=26\&Itemid=78\&lang=sr $\underline{\text { \&limitstart }=2}$ (last access: Feb. 2012).

75 The government plans to close down 22 agencies out of 130, among which is the EA. Reported by Tanjug, Večernje Novosti at 6 Sept. 2012, available at: http://www.naslovi.net/2012-09-06/b92/za-brisanje-22agencije/3829898 (last access: Feb. 2013).
} 


\section{A.Fejös, The Impact of EU Norms and Policies on Consumer Protection Enforcement in} Serbia available at link.springer.com

consumer protection, the principal government institution facilitating consumer protection policy and oversight of the CPA has changed three ministries within the past four years. ${ }^{76}$

Changes to the law are too frequent, without paying attention to the aggregate positive and negative effects of the existing law or the change (Milovanovic 2009). Additionally, the government on occasion does not respect the law itself, at least not the CPA. For instance, under Art. 153 CPA certain secondary legislation for the enforcement of the CPA was supposed to be adopted within six months, but has still to be adopted after two years of operation of the new law. Moreover, Art. 126 CPA provided for the establishment of the National Council for Consumer Protection (NCCP) as a principal advice body to the Ministry, yet it was almost a year and a half after the CPA entered into force before the NCCP was actually established. ${ }^{77}$ Further, Art. 124 CPA envisages a National Strategy for Consumer Protection containing long term aims, and which is in practice realized via an Action Plan for the period of five years, yet neither the Strategy nor the Action Plan have been adopted up to the date of finalizing this paper. Additionally, the National Program for Consumer Protection for 2007-2012 ${ }^{78}$ will soon expire, without there being a new program for the upcoming period.

In addition, political interests and biases often undermine the stability of enforcement. The underlying reasons for the lack of enforcement are often not the absence of legal regulation, or the unavailability of enforcement mechanisms, but rather in the lack of (political) will to use the available powers. For example for several years credit contracts secured by mortgage contained a clause according to which banks could change one component of the interest rate, the margin of the bank, according to their business policy. The only obligation banks had was to notify the consumer in writing on the change. This was clearly an unfair term, which allowed the bank to change one of the core elements of the contract without any objective and foreseeable criteria. It was an unfair term according to the

\footnotetext{
${ }^{76}$ It is currently within the Ministry of External and Internal Trade and Telecommunications (Act on Ministries OG RS No. 72/12), it was part of the Ministry of Agriculture, Trade, Forestry and Water Management between 2011 and 2012 (Act on Ministries OG RS No. 16/11), and before it belonged to the Ministry of Trade and Services from 2007 when it was established until 2011 (Act on Ministries OG RS No. 43/07 and Act on Ministries 65/08, 36/09, 73/10).

77 The National Council for Consumer Protection has been established on October 18, 2012 http://www.zastitapotrosaca.gov.rs/vesti.php?naslov=nacionalni-savet-za-zastitu-potrosaca (last access: Feb. 2013)

${ }^{78}$ Government Decree on the National Program for Consumer Protection from 2007 until 2012 (Uredba o utvrđivanju Nacionalnog programa zaštite potrošača od 2007. do 2012. godine), OG RS No. 11/2007.
} 


\section{A.Fejös, The Impact of EU Norms and Policies on Consumer Protection Enforcement in Serbia available at link.springer.com}

general rules of contract law, ${ }^{79}$ and according to the Art. 44 CPA. However, it was an established practice of banks to incorporate the clause into their contracts, and on several occasions they took advantage of it by raising loan interest rates, especially during the financial crisis. The practice of the banks was well known to everyone, especially the NBS, as the CPEFSU received a number of complaints on this ground. And yet the NBS, being the supervisory authority for financial service providers, did not use any of its powers to issue fines or commence misdemeanour proceedings. In November 2011 the FSUPA came into force expressly forbidding such contract clauses, in both future and currently running contracts, subject to high fines. It has to be underlined that the principal drafter who possibly inserted the provision into the law was, in fact, the NBS. Moreover, contrary to its previous practice, the NBS started to enforce the law, and issued several fines against banks for noncompliance with the FSUPA. Namely, as a measure to mitigate the consequences of unilateral amendment of the interest rates based on Art. 54(2) FSUPA the banks were obliged to adjust the variable component of the interest rate to the maximum level that it had at the moment of contract conclusion. Two banks that failed to initiate contract amendments in timely manner were subject to 11 fines. ${ }^{80}$ One question is why it took so long for the NBS to begin to take such proper enforcement action and the answer is probably to be found in the wider, political, legal and economic context. The NBS was most probably protecting the banks, which are mostly built on foreign capital, being afraid of their withdrawal from the market. This protection should be understood together with high capital requirements, difficulties to collect outstanding debt, and the relatively minor importance of breaches compared to the perceived benefit brought by the foreign banks. Since the debt collection problem has been eased, and the capital requirements lowered, the NBS changed its policy, enforcing the consumer protection laws at least to some extent. ${ }^{81}$ This example nevertheless shows how political biases can compromise the effectiveness of consumer protection enforcement.

\footnotetext{
79 Art. 12 (the general principle of good faith); Art. 46 (a contractual obligation should be determined or determinable) Law of Obligations Act of 1978 (Zakon o obligacionim odnosima) OG SFRY Nos. 29/78, 39/85, 45/89, 57/89 and OG FRY No. 31/93.

${ }^{80} \mathrm{See}$ http://efektiva.rs/aktuelnosti-krediti/kbc-i-alfa-banka-moraju-da-plate-55-miliona-dinara-posle-prijavaklijenata referring to Blic (daily newspaper) of 25 April 2012 (last assess: Sept. 2012). Unfortunately, there is no available data on the exact number of fines, as contrary to its obligation from Art. 45(5) FSUPA the NBS failed to publish information on the banks that did not comply with the FSUPA.

${ }^{81}$ The author is grateful to $\mathrm{Lj}$. Kontić for help on this point given in an informal conversation in June 2012.
} 
A.Fejös, The Impact of EU Norms and Policies on Consumer Protection Enforcement in Serbia available at link.springer.com

\section{Recommendations for a More Efficient Consumer Protection Enforcement in Serbia}

Based on the above analysis, some suggestions can be made for improving the system of consumer protection enforcement in Serbia in line with EU norms and policies.

\section{IV.1. Special ADR Mechanism for Solving Consumer Disputes}

Since ADR significantly contributes to consumers' access to justice (Leuven Study 2007 p. p. 36-39; Benöhr 2012a, p. 2) ${ }^{82}$ it appears necessary for Serbia to have an operational ADR mechanism for solving consumer disputes. There is no ideal system of ADR, nor is there an ideal mix of different ADR mechanisms (Leuven Study 2007 p. 7). The possibilities are wide, and currently there are around 750 different ADR models in the EU (Benöhr 2012). Each jurisdiction has to choose the most appropriate ADR method and their combination. It is important that the chosen model fits well into the existing legal and administrative framework that it takes into account the existing models and effectiveness of judicial proceedings, the structure of businesses and the organization of consumers, the system of market surveillance and the operation of the administration. Additionally, the choice should reflect historic, legal, political, socio-economic, educational and cultural factors (Leuven Study 2007 p. 7).

Access to justice has been recognized as a human right under Art. 6 of the European Convention of Human Rights. Besides access to justice, Art. 6 contains a guarantee of the right to a fair trial. Art. 47 of the Charter of Fundamental Rights of the EU provides for the "right to an effective remedy and to a fair trial" (Benöhr 2012a, p. 3). Therefore, the ADR model should not only provide access to justice in Serbia, but also respect the right for fair trial. Fair trial means a number of procedural guarantee that relate to the process as a whole (see for more Brems 2005).

Without going into details, the special model for Serbia, whichever its name would be, should provide for a fast, cheap, accessible solution, and end with a binding decision. The procedure should be conducted by trained personnel on consumer protection, and any dispute resolution panel could be comprised of both the representatives of traders and consumers. It

\footnotetext{
${ }^{82}$ J. Stuyck, E. Terryn and others, University of Leuven Study, An analysis and evaluation of alternative means of consumer redress other than redress through ordinary judicial proceedings, January 17. 2007 (Leuven Study 2007)
} 


\section{A.Fejös, The Impact of EU Norms and Policies on Consumer Protection Enforcement in Serbia available at link.springer.com}

would be preferable to apply a mixed procedure, which firstly aims to mediate between the parties, and only thereafter renders decision on the merits of the case. The reason for this is that an agreement, where the parties participate in its formulation, is more easily acceptable to them; but if mediation is unsuccessful the ADR body should be competent to render a binding decision on the matter. The ADR bodies should be independent and impartial, be bound only by the law, and ethical and moral rules (Fejös 2009). The Arbitration Boards of Hungary could serve as a model, with slight modifications (Fejös 2008). In order to remedy the deficiencies in the present ADR mechanisms it would be key to make the decision of the ADR body binding on the parties. Additionally, the best results would be achieved if submission to the process would be obligatory for the parties, as one of the key reasons existing ADR mechanisms are not successful is their voluntary character, allowing businesses to refuse to take part. However, since making the ADR scheme binding on the parties may limit the right of the parties to fair trial, it is important that fair trial is protected by a number of guarantees. These should especially include a guarantee that the ADR body consists of experts, has procedural guarantees similar to the judicial process, and in the absence of an appeal, there is a possibility of annulment by the courts (similar to Art. 58 of Arbitration Act) or of commencing a court action on the same matter as it is provided in Art. 135 CPA.

It is worth to note the creation of a special ADR for consumer disputes is currently on the agenda in Serbia, but at the time of finalizing the paper the paper the outcome is uncertain. ${ }^{83}$

IV.2. The funding and professionalism of consumer organizations

Even though the CPA gives important powers to consumer organizations, in practice they do not have capacity to properly take advantage of the designated powers. As indicated, the primary problem is the lack of sufficient and constant funding that would allow organisations to build up and employ relevant experts.

The CPA states that registered consumer organizations "may" be financed from the budget of the central, regional or local government, leaving it unclear whether they must or

\footnotetext{
${ }^{83}$ The second EU funded project for strengthening consumer protection in Serbia (2011-2014) plans to make a proposal on the creation of a special ADR for consumer disputes to the Ministry within amendments to the CPA. See: http://www.zapotrosace.rs/en/index.php (last access: May 2013). This is however not conclusive, as a special ADR mechanism was part of the proposed version of the current CPA but it did not become a reality.
} 
A.Fejös, The Impact of EU Norms and Policies on Consumer Protection Enforcement in Serbia available at link.springer.com

they can be financed this way. The other alternative the CPA provides for is financing by rendering services such as training (Art. 131 CPA).

There are several ways in which financing may be improved. Introducing class or group actions and allowing consumer organizations to retain a share of settlement, or recover their costs after a judgment is rendered against the business is one example. This solution would bring a dual benefit, as consumers could settle their claim for damages, and consumer organizations could get reimbursed their expenses. In addition, if consumers would decline interest in collecting damages the uncollected money could be an additional source for financing for consumer organizations. This practice of financing is used in the USA (Hensler 2010). Though administrative enforcement does not bring pecuniary damages for consumers, administrative fines could be used for the benefit of consumers. For example a fund could be created where all the fines from competition infringements would go instead of flowing into the state budget, as it is at the present. A detailed analysis of these proposed solutions goes beyond the scope of the paper (see more in Benöhr 2012). Nevertheless, since consumer organizations are the only non-governmental organizations that cannot be financed directly from businesses, the role of government in financing of consumer organizations should be increased, and be settled in a more explicit way.

The importance of funding for the goal of professionalization of consumer organizations can be demonstrated by the positive achievements of Advice Centres. Previously consumers were advised on ad hoc basis, by a person that "first picked up the phone", and the advice that was given often had no basis in the law. The creation of Advice Centres greatly contributed to the professionalization of consumer organizations, by granting them resources to employ a lawyer. The lawyers employed in Advice Centres are mostly at an early stage in their career, which in turn has led to the increase in the interest among graduates and young professionals towards possible carriers in consumer protection. The increase of funding would allow the employment of more lawyers, that could have duties other than giving advice to consumers potentially contributing to consumers' access to justice. However, the increase of funding should go hand in hand with making the funding stable, as at the moment the Advice Centres are funded on a yearly project basis. This means, at least in theory that the Advice Centre operated this year by one organization may be located next year in another organization. Such uncertainly is not good either from the aspect of consumers or from the lawyers that work in the Advice Centres. 
A.Fejös, The Impact of EU Norms and Policies on Consumer Protection Enforcement in Serbia available at link.springer.com

The example of Efektiva shows that alternative ways of funding, from membership fees and rendering professional services is also possible. But it should be born in mind that the "new model" of consumer organizations might not work in other areas of consumer protection. Namely, Efketiva is specializing in protecting banking clients. It is directed not only towards consumers but also legal persons. It was formed at an opportune political moment, after the adoption of the FSUPA. It provides help in the area that requires highly professional knowledge and information which the majority of consumers are willing to pay for. Finally, court actions are directed against banks, which as losing parties are likely to have sufficient funds to pay for the expenses of the organization. Although the model might work in other areas of consumer protection, and consumer organizations should be encouraged to find alternative sources of funding, the Government should not be relieved from its funding responsibility. Government funding, especially targeted funding towards litigation should be encouraged. In EU only a few consumer organisations are effective litigants, and these are exactly the organizations in Germany and Austria that rely almost entirely on government funding (Cafaggi and Micklitz 2008, p. 24).

IV.3. Standing to protect the collective interests of consumers to the Commission for the Protection of Competition

In order to increase the level of consumer protection in Serbia, one option is to spread the burden by empowering the CPC to sue for violations of unfair terms and unfair commercial practices, and to represent the collective interests of consumers.

The CPC is suitable to represent consumer's interests. It is a public agency that enjoys the highest degree of independence. It has sufficient funds and manpower. It mostly enjoys good reputation and authority, and the protection of consumers and their welfare is within its purposes. It has a general jurisdiction. It has significant investigative and enforcement powers. The CPC is therefore more suitable to pursue collective actions, than the other sector specific public agencies entrusted with consumer protection enforcement.

In the majority of EU jurisdictions, besides consumer organizations, public agencies are also empowered to protect the collective interests of consumers (Leuven study p. 324). Taking the example of the battle against unfair terms in the UK, the activities of Office of Fair Trading (OFT) significantly improved the protection of consumers. Before granting 


\section{A.Fejös, The Impact of EU Norms and Policies on Consumer Protection Enforcement in} Serbia available at link.springer.com

enforcement powers to the OFT, the only form of enforcement was private litigation. ${ }^{84}$ As the judgment's effect only between the parties in the dispute was not a deterrent and sufficient to eliminate unfair contract terms from the marketplace, private enforcement was largely ineffective (Willett 2007, p. 405). After legislative changes, Reg. 12 of the Unfair Contract Terms Regulation 1999 (UTCCR) conferred on a variety of bodies power to seek injunctions, among which the OFT took a leading role. In addition to injunctions, the OFT may ask the business to remove or amend the terms of the contract (Reg. 10 UTCCR). This proactive role of the OFT is very important, and successful in eliminating unfair terms from the contract before any harm would be done. Within its proactive role it issued principles and guidelines how to avoid the use of unfair terms. ${ }^{85}$

Therefore, a public authority as the CPC has resources and powers to detect the unfair terms, and to eliminate them from the contract. Also, the mere existence of such an authority is a deterrent factor for a business to use unfair terms in consumer contracts. Besides annulling the term, and forbidding its future use, the public authorities have means and resources to ensure businesses will not continue the use of the same or a very similar term having equivalent economic effect. This task could be better entrusted to powerful and independent public agency than to courts, which do not have monitoring powers over the contracts, and are slow in solving disputes.

Furthermore, the EU policy seems to go towards the dominance of public enforcement, so that for instance EC Regulation 2004/2006 ${ }^{86}$ calls for one public authority to be designated that will be responsible for cross-border enforcement. While the regulation applies only to cross-border issues, it clearly shows the intention of the European Commission to place domestic enforcement into the hands of public agencies (Micklitz 2010, p. 45).

Finally, as judicial collective enforcement mechanism largely depends on national regulatory traditions and cultures (Cafaggi and Micklitz 2007, p. 9) and taking into account that these are exactly the reasons why some enforcement mechanisms in Serbia are not

\footnotetext{
${ }^{84} \S 6(2)$ and 7(2) of the Unfair Contract Terms Act of 1977

${ }^{85}$ The most notable are the briefing note on Unfair standard terms (OFT143, revised 2005), and the comprehensive Unfair contract terms guidance (OFT311), published 2001).

${ }^{86}$ Regulation (EC) No 2006/2004 of the European Parliament and of the Council of 27 October 2004 on cooperation between national authorities responsible for the enforcement of consumer protection laws, OJ L 364, 9.12.2004, p. 1-11
} 


\section{A.Fejös, The Impact of EU Norms and Policies on Consumer Protection Enforcement in}

Serbia available at link.springer.com

working, a designated and strong public agency may have more potential to influence cultural gaps.

\section{Conclusion}

One can say that the rights of consumers are protected when the interaction of enforcement mechanism and substantive rules provides fast, affordable, impartial, enforceable and accessible solutions. At first sight it seems that Serbia has a "healthy" combination of administrative and judicial enforcement. However, by examining the system in detail, one can observe serious loopholes and conclude that enforcement is not working well.

EU norms have brought some fundamental changes to Serbian enforcement mechanisms at a formal level, both in relation to mediation processes at the individual/ADR level and, perhaps much more significantly, the use of injunctions as a means of preventive and collective control. However, in practice, their impact is still very limited and consumers often end up with no effective protection if they do not opt for individual litigation. One important response to this would be a special ADR mechanism for solving consumer to business disputes which has improved sanctions and overcomes the problems of the anticompliance business culture. Another priority is to improve the funding for consumer organizations to strengthen their ability to pursue injunctive relief; and to spread the burden of this preventive control by also empowering the CPC to seek injunctions.

However, it is not only the EU norms related to mediation and injunctions that are affected by the enforcement problems "on the ground" in Serbia. The general EU policy objective of effective enforcement is compromised within the broader enforcement framework of Serbia in several ways. Enforcement powers of public agencies are undermined by their lack of power to impose sanctions or other effective remedies. Enforcement by inspectorates is not working well due to the lack consumer protection culture and often the lack of expertise of inspectors. Finally, these specific problems are followed by a general political, legislative and institutional instability the overarching political, legislative and institutional instability.

Some of the above problems in relation to effective enforcement in the general system could be addressed by improving the powers of public agencies and the accountability of the inspectorates. However, ultimately, as consumer protection goes to the heart of the overall social order, until some underlying values change, it will be difficult to create a genuinely 
A.Fejös, The Impact of EU Norms and Policies on Consumer Protection Enforcement in Serbia available at link.springer.com

effective system of consumer protection. As one Serbian politician commented, without (political) will to enforce, no statutory laws will help. ${ }^{87}$

\section{References:}

The author is thankful for help and advice to C. Willett (University of Essex), T. Jovanić (University of Belgrade), Lj. Kontić (Faculty of Legal and Business Studies, dr Lazar Vrkatić), colleagues in consumer protection organizations, and to the employees in public agencies and government organs. The author is also thankful for the valuable input of the two anonymous reviewers on earlier draft of the paper. All mistakes remain the responsibility of the author.

Aleksić, D. (2012). “Agentification of Serbia” (“Agencifikacija”) Srbije, Macroeconomic Analysis and Trends, May 2012, 36-40.

Benöhr, I. (2012). Consumer Dispute Resolution after The Lisbon Treaty: Collective Actions and Alternative Procedures, Journal of Consumer Policy, July 2012.

Benöhr, I. (2012a). Alternative dispute resolution for consumers in the EU. In C. Hodges, I. Benöhr, \& N. Creutzfeld-Banda (Eds.), Consumer ADR in Europe (pp. 1-25). Oxford: Hart Publishing.

Beljanski, S. (2008). Regulatory and Enforcement Agencies in the Repulbic of Serbia (Regulatorna i kontrolna tela u Republici Srbiji), Survey-Republic of Serbia, 2, 57-74.

Brems, E. (2005) Conflicting Human Rights: An Exploration in the Context of the Right to a Fair Trial in the European Convention for the Protection of Human Rights and Fundamental Freedoms, Human Rights Quarterly 27, 294-326.

Cafaggi, F. \& Micklitz, H-W. (2007). Administrative and Judicial Collective Enforcement of Consumer Law in the US and the European Community. EUI Law Working Paper, 22.

Cafaggi. F. \& Micklitz, H-W. (2008) Administrative and Judicial Enforcement in Consumer Protection: The Way Forward, EUI Law Working Paper, 29.

Cafaggi, F. (2008-2009).) The great tranformaiton. Administrative and Judicial Enforcement in Consumer Protection: a remedial perspective, Loyola Consumer Law Review, 21, 496-539

Czuczai, J. (2006). Final Report on Assessment of EU Consistency of Serbia/Montenegro Regulatory Framework for Consumer Protection, Belgrade-Podgorica: PLAC.

Dimitrijević, P. (1983). Foundations of Administrative Law (Osnovi upravnog prava), Belgrade: Faculty of Law.

Feješ (Fejős), A. (2008). Consumer Arbitration Boards in Hungary - a Model for Out-of-Court Consumer Dispute Settlement in Serbia? (Potrošačka mirovna tela u Mađarskoj - model vansudskog rešavanja sporova potrošača u Srbiji?). Legal Life, 13, 483-500.

Feješ (Fejős), A. (2009). Out-of-Court Consumer Dispute Resolution in Serbia: Current State and Recommendations for the Future (Vansudsko rešavanje sporova potrošača u Srbiji: sadašnje stanje i preporuke za novu zakonsku regulativu), New Legal Solutions in Consumer Protection, 43-58.

\footnotetext{
${ }^{87}$ Speech of MP Gordana Pop-Lazić in National Parliament of Serbia during the parliamentary discussion on the Administrative Inspectorate Act, October 2011, available at: http://www.youtube.com/watch?v=A3cpTolENys
} 
A.Fejös, The Impact of EU Norms and Policies on Consumer Protection Enforcement in Serbia available at link.springer.com

Hensler, D. R. (2010). Using class actions to enforce consumer protection law. In G. Howells \& I. Ramsay \&T. Wilhelmsson (Eds.), Handbook of Research on International Consumer Law (pp. 515-536) Chaltenham \& Northampton: Edward Elgar.

Karanikić Mirić, M. (2010). What is new in Serbian consumer (contract) law?, (Šta je novo u Srpskom (ugovornom) potrošačkom pravu?), Legal capacities of Serbia for European integrations, 5,127-146.

Kovačević, Lj. (2006). About mediation (O medijacija), Legal Life, 12, 265-278.

Micklitz, H.-W. (2010). Consumer law, In F. Cafaggi \& O. O. Cherednychenko \& M. Cremona \& K. Cseres \& L. Gorywoda \& R. Karova \& H.-W. Micklitz \& K. Podstawa, Europeanization of Private Law in Central and Eastern Europe Countries (CEECs): Preliminary Findings and Research Agenda (pp. 35-46). EUI Law Working Papers, 15.

Micklitz, H-W. (2012). Europeanisation of private law in the CEECs and SEECs. The Case of Consumer Protection, Paper presented at the Thirteenth Mediterranean Research Meeting, Florence and Montecatini Terme 21-24 March 2012, organised by the Robert Schuman Centre for Advanced Studies at the European University Institute.

Milovanović, D. (2009). The Reform of Control by Inspection Surveillance (Reforma sistema inspekcijskog nadzora), Legal Life, 11, 5-21

Papović, G. \& Feješ (Fejős), A. (2008). The Role of Stabilization and Association Agreement in Consumer Protection (Uloga Sporazuma o stabilizaciji i pridruživanju u zaštiti potrošača), Challenges of European Integration, 1. 45-60

Piché, C. (2009). The Cultural Analysis of Class Action Law, Journal of Civil Law Studies, 2, 101-144.

Radojević, M. (2010). Independent (Regoluatory) Agencies and Institutions in Serbia (Nezavisna (regulatorne) tela i institucije u Srbiji), Serbian Political Thinking, 4, 5376.

Reich, N. (2009). Legal Protection of Individual and Collective Consumer Interests. In H.-W. Micklitz, N. Reich, P. Rott, Understanding EU Consumer Law (pp. 317-361) Antwerp-Oxford-Portland: Intersentia.

Scott, C. (2010). Enforcing consumer protection laws. In G. Howells \& I. Ramsay \&T. Wilhelmsson (Eds.), Handbook of Research on International Consumer Law (pp. 537562) Chaltenham \& Northampton: Edward Elgar.

Stanojev, V. (2009). Rights, Duties and Powers of Inspectorates (Prava, dužnosti i ovlašćenja inspekcijskih organa), Bar Association of Vojvdina Herald, Book, 10, 435-441.

Šuput, D. (2009). Independent Regulatory Bodies in the Legal System of the Republic of Serbia (Samostalna regulatorna tela u pravnom sistemu Republike Srbije), Telecommunications, 3. at http://www.telekomunikacije.rs

Tomić, Z. (2009). General administrative law (Opšte upravno pravo), Belgrade: Faculty of Law.

Tomić, N. (2003). The accountability and efficiency of inspectors in the legal system of Serbia and Montenegro (Odgovornost i efikasnost inspektora u pravnom sistemu Srbije i Crne Gore), Annals of the Faculty of Law in Belgrade, 51, 127-143

Vasiljević, M. (2009). Business Law of Serbia and the European Union (Poslovno pravo Srbije i Evropska unija), Law and Economy, 5-8, 1-22.

Willett, C. (2007). Fairness in Consumer Contracts; The Case of Unfair Terms. Aldershot: Ashgate. 